Author Index Vol. 124, 2001

\section{International Archives of \\ Allergy $y_{\text {ax }}$ \\ Immunology}

Agea, E. 497

Baur, X. 502

Benedictis, F.M. de 497

Bertotto, A. 497

Bistoni, O. 497

Bologni, D. 497

Bröcker, E.B. 461

Cho, S.H. 478

Duschl, A. 461

Endo, T. 485

Fujimaki, H. 485

Fujisawa, T. 470

Grunewald, S.M. 461

Hahn, C. 461

Hartleroad, J.Y. 478

Hirai, K. 470
For the Author Index of No. 1-3, please see pp. 417-419

Hoogsteden, H.C. 432

Iikura, M. 470

Kaplan, A.P. 423

Lambrecht, B.N. 432

Merget, R. 502

Minelli, L. 497

Miyamasu, M. 470

Morita, Y. 470

Müller, U.R. 447

Nakajima, T. 470

Nelde, A. 461

Nohara, K. 485

Oh, C.K. 478

Okumura, Y. 454

Pauwels, R.A. 432

Ra, C. 470
Raulf-Heimsoth, M. 502

Russano, A. 497

Sander, I. 502

Sebald, W. 461

Spinozzi, F. 497

Takahashi, K. 454

Takai, T. 454

Teufel, M. 461

Ui, N. 485

Ushio, H. 485

Yamada, H. 470

Yamaguchi, M. 470

Yamamoto, K. 470

Yasuhara, T. 454

Yokota, T. 454

\title{
Subject Index Vol. 124, 2001
}

For the Subject Index of No. 1-3, please see pp. 420-422

Adjuvant 485

Airway 461

(R)-Albuterol 478

(S)-Albuterol 478

Allergic sensitisation 461

Allergy 432, 461, 485, 502

$\alpha$-Amylase 502

Animal model 432, 461

Antibodies 461

Antigen-presenting cells 432

Antihistamines 447

Asthma 432, 478, 497

Baker's asthma 502

Basophils 423

Cellulase 502

Chemokine 423

Cord blood 497

Cysteine protease 454

Cytokines 497
Dendritic cells 432

Diesel exhaust particles 485

Disulfide bond 454

Enzymes 502

Eosinophils 423, 470

Eotaxin 423

FceRI 470

Flow cytometry 470

N-Glycosylation 454

Histamine 478

Honeybee 447

House dust mite 454

Hymenoptera venom allergy 447

IgE 461,470

IL-4 470

Immunology 432

Insect SF9 cell 454

Interleukin-4 478

Lymphocytes 423
Mast cells 478

Mastocytosis 447

Maturation 454

Monocytes 423

Newborns 497

Pichia pastoris 454

RANTES 423

Receptors 423

Recombinant Der f 1454

- venom allergens 447

Secretion 454

Site-directed mutagenesis 454

T lymphocytes 497

Th1/Th2 485

Th2 cells 497

Venom immunotherapy 447

Vespula 447

Xylanase 502

\section{KARGER}

(C) 2001 S. Karger AG, Basel

Fax + 41613061234

E-Mail karger@karger.ch

www. karger.com 